\title{
Emotions and community development after return migration in the rural Arctic
}

\author{
Marit Aure and Larissa Riabova
}

\section{Emotions in return migration and rural development}

Migration is highly emotional (Castles, de Haas, and Miller 2014) and often evokes strong feelings of optimism for human and economic development in societies of origin. In 1998, during a period of harsh economic and political transition in Russia, temporary labour migration started from Teriberka, a small, remote Russian village on the Barents Sea coast, to Båtsfjord, an equally small village in the Norwegian Arctic. The labour mobility programme brought about 40 villagers, mainly women, to work in the fish-processing industry in Båtsfjord. Most of the migrants were formerly employed at the kolkhoz in Teriberka - a fishing and fish-processing collective farm established in the Soviet era. The migration was designed to fit Norwegian regulations, which restricted the work to two years of unskilled jobs in the fish-processing industry in northern Norway for Russian workers (no families). The mobility programme was organised by Norwegian and Russian businessmen as part of a broader development project in Teriberka.

The migration organisers, most migrants, villagers, and politicians expected that the migration would improve the migrants' and their families' situation and catalyse economic activity and development in the declining Russian village. They hoped for a better life for migrants and the community, while fear, euphoria, joy, homesickness, disillusionment, and nostalgia for the Soviet past were other strong feelings. With extensions of the work permits, the migration ceased after three years and most migrants returned to Teriberka. Thus, return migration occurred, which refers to migrants returning to their countries of origin or later generations returning to their family's homeland (Kunoroglu et al. 2016). In Teriberka, the migrants returned after backand-forth migration but the expected developmental outcomes of migration were not achieved. The extent of the emotional strain contained in people's stories drove us to acknowledge affectivity as a way of comprehending the world (Markussen 2006). This motivated our examination of the emotional underpinnings of this rural return migration and its lack of impact on the development of Teriberka. 
Research on return migration has, since the 1960s, shown that few return migrants engage in cooperative or economic development efforts (King 1986, Christou 2006, Vathi and Duci 2015). King (1986, 20) also states that the belief that human capital improves after return migration has '[been] shown to be almost entirely fallacious,' highlighting that return migrants do not play the role as catalysts for economic development in their home communities, in opposition to expectations such as in Teriberka in this study. However, contrary to King (1986), we observed, and the migrants highlighted, improvements in their human capital during migration. Despite this, the expectations of rural development after the migrants' return went unmet in Teriberka.

Kunuroglu, Vijver, and Yagmur $(2016,10)$ point to return migration and its impact as a 'multi-layered phenomenon influenced by multiple interrelated factors' which neither economic perspectives, transnationalism, nor reacculturation theories explain. Cassarino $(2004,254)$ suggests that understanding 'the link between migration and development... requires revisiting approaches to return migration and distinguishing between different forms of migration.' Our focus on the role of emotions in explaining the lack of rural development after the return of temporary labour migrants in a postSoviet context responds to these requests. While King (1986) and later writers reveal the lack of post-return migration development, we attempt to understand and explain why this is the case. Paraphrasing Ahmed (2004), we ask what emotions do during the migratory process and what analysing emotions does to the understanding of the development impact in societies of origin.

Examining migration requires investigating the situation before migration, the migration itself, the situation abroad, the return migration, and the situation after return (King 1986). We enquire about the role of emotions among individuals, social groups, and the community across these phases, with a particular focus on the (lack of) development in the origin community in the post-migration phase. We argue that emotions play a significant role in expectations and considerations in the migratory process. To support our contention, we explain how migrants use emotional experiences abroad in individual strategies, showing how emotion increases the post-return disappointment imposed by the lack of public policies for rural development. The positive migration experiences are to a lesser degree used at the community level as they are not being met by state or municipal strategies. Focus on emotions hence makes visible the impact of economic and political state policies on people's actions. This chapter adds to clarifying the ambiguity of international mobility in rural places (Aure, Førde, and Magnussen 2018) and the role of emotions in various migration phases.

\section{Emotions in migration and development}

During the past two decades, emotion has increasingly been used as a lens to (re)examine aspects of individual, group, organisational, and community life 
(Tanner 2005, 122). There is also a growing interest in emotions in migrations studies (Carling and Collins 2018). However, although Castles, de Haas, and Miller (2014) find migration highly emotive, they and others have paid little attention to the role of emotions across different phases of migration and especially in the return phase. While Halfacree (2004) highlights the non-economic worlds of migration, the role of emotions seems missing in studies of return migration and rural development. We find that discussions on emotions in migration studies centre on emotional labour (Hochschild 1979), the emotional constitution of the migrant subject (Ahmed 2004), and transnational families, diasporas, and the emotional costs of migration (Svašek 2010, 865). There is rarely focus on emotions in studies of migrant labour markets (Aure 2013). Theoretically, there is a development towards understanding the role of social imaginaries of migration (Benson and Osbaldiston 2014), although the concept's relationship to the emotions remains unclear (O'Reilly 2014).

We see emotions as 'processes in which individuals experience, shape and interpret the world around them, anticipate future action and shape their subjectivities' (Svašek 2008, 218). Emotions may be social, as in shared experiences (Heady and Miller 2006); physical and 'culturally elaborated ..., socially and historically nuanced and thus variable'; and structured and structuring (Burkitt 1997, 39). Rather than seeing reason and passion as opposites, we consider them relational and complementary, with neither taking precedence over the other (Burkitt 1997).

Heady and Miller (2006) use the concept of 'emotional capital' to ascertain the role of emotions in rural development, arguing that economic activity requires not merely mental, physical, and rational efforts but also emotional orientations, as rational behaviour also rests on irrational premises. Emotional capital may be a form of social capital (Nowotny 1981) or cultural capital (Reay 2000); we apply emotional capital as an analytical tool that describes a set of resources inherent to individuals and useful for development through informing action (Gendron 2017, Voronov 2013), and also at the community level. This means that migration memories present in Teriberka '[seem like] individual knowledge of the past,' and shared memory (history) may work as 'the cognitive maps' of communities (Heady and Miller 2006, 34-35). Hence, emotional capital is accumulated stocks of emotional resources formed by positive and negative emotional experiences constituting a resource inherent to particular practices. These resources form relational skills, self-esteem, adaptability, and other emotional competencies (Gendron 2017). We highlight emotions to include what is often excluded as being non-rational - fear, joy, anger, and so forth - and show how this adds to the understanding of migration and the lack of post-return rural development.

\section{A multi-sited study of organised labour migration}

This analysis draws on longitudinal, connected community studies in Teriberka and Båtsfjord from 1996 to 2018, a suitable time span to discuss the 
intersection of return migration and rural development. The main study was carried out in Teriberka and Båtsfjord in 1998 to 2002, with follow-up studies in both villages in 2012 and in Teriberka in 2015. Preliminary material was collected in 1996 in Teriberka and since then the village has been monitored through visits, interviews, phone calls, documents, and register studies. This provides narratives before the migration, during the migration in Båtsfjord, upon migrants' return, and after the migration ended.

Although the migrants were employed as unskilled workers, many had backgrounds as engineers, economists, and administrators. Thirty-seven of the 40 migrants were women, from 22 to 46 years old, a distribution resulting from the Norwegian businessmen's requirements based on gendered work in the Norwegian fish processing industry (Aure 2011).

Our qualitative methods included interviews, ethnographic field talks, and notes from participant and non-participant observations. Altogether, 16 migrants were interviewed once or several times, individually or in focus groups. Information regarding other migrants was also obtained through interviews. We interviewed employers, managers, family members, co-workers, and political and administrative leaders in Russia and Norway. The main study involved 74 Russians and 74 Norwegians. Migrant interviews employed a 'life course' approach aimed at understanding migration experiences, everyday life, and the local context. The interviews lasted from one and half to two hours, discussing life at home and abroad, family, education, work, spare time, civil activities, networks, and opinions on the past, present, and future of Teriberka. In some interviews, emotions were an important theme, and in others they were present but not explicit - the analysis includes both. We believe the theme and the ambience produced in the long-term interactions inspired these discussions. Excerpts from the respondents' narratives and our observations support this argument and provide examples of people's expression of thoughts, practices, and emotions. As this regards a group of people from a small village, anonymity prevents us from expanding on the migrants' biographies, and to protect the co-workers and interviewees their names have been anonymised.

\section{Cross-border labour migration: when emotional capital grows}

Teriberka, the home of 900 people, stands on a windy coast $450 \mathrm{~km}$ above the Arctic Circle. The nearest cities are Severomorsk, the naval base, and Murmansk, the capital of the region, which is a two- to three-hour drive through empty tundra. Teriberka is one of the oldest and, formerly, wealthiest fishing communities on the Kola Peninsula, inhabited for 500 years by Russians, Pomors, Sami, Norwegians, and Finns. Teriberka had strong international ties across the Barents, White, and Norwegian Seas until the Russian Revolution in 1917. In the Soviet era, Teriberka flourished, growing 
to about 5,000 inhabitants due to its fishing industry and shipyard. However, in the mid-1960s most industries were moved to Murmansk and the number of inhabitants had declined to 1,732 by 1997 (Riabova 2001, 123). Until 2009 , the village was under a military border regime with restricted access for foreigners. Market reforms in the early 1990s caused a deep socio-economic crisis, and local unemployment reached $40-50$ per cent. The situation led to children coming to the village hospital to ask for bread (Riabova 2001). Many people were desperate and many of those who secured permission to leave for work did so.

\section{Migration to Båtsfjord}

By the late 1990s, the situation in Teriberka was more complicated than ever. Then, Russian businessmen who formerly worked in Teriberka and their Norwegian partners from Båtsfjord established a project with help from the government of the Murmansk region and local mayors. They invited villagers to train and work as unskilled filleters in the fish-processing industry in Norway (Aure 2008, Riabova and Ivanova 2009). Some of the migrants were among the first group recruited; others arrived in Båtsfjord later. The migrants and the migration organisers learned along the way that the regulated two-year term was counted day by day, and this decided their actual stay abroad. All migrants returned home for Christmas and several weeks in summer, while some had their families visit. As the migrants became familiar with the road, they drove between Teriberka and Båtsfjord in private cars (about 600km), although the roads were bad and regularly closed due to snowstorms. Yet other migrants stayed as long as possible to earn as much as possible, and saved time and money by not visiting home. A few were sent home due to problems we cannot expand on for reasons of anonymity, and some resigned. Most migrants lived in low-quality dormitories and had the rent deducted from their salaries. They were paid minimum wage without increases for seniority.

The following section presents the emotions inherent in the migration process, starting with the recruitment phase, followed by the experiences of life in Båtsfjord and migrants' hopes for the future. The next section focuses on the return and the post-return situation in Teriberka and migrants' imaginaries, emotions, and practices. In the conclusion, we discuss emotions in migration and their role in the lack of post-return rural development.

\section{Recruitment, considerations, and migrant life in Båtsfjord}

In 1998, rumours abounded about the prospects of migrating to Norway and created strong feelings in Teriberka: the migration organisers and most villagers saw work in Båtsfjord as a prize. Candidates were interviewed carefully before they were selected and completed the 15-hour drive to Båtsfjord in 
a chartered bus organised and prepaid by the businesses, with the travel costs later reimbursed by the migrants. Living in an isolated society, few migrants had previously been abroad or had international passports, and many feared the unknown. Pavel, a young migration organiser, explained:

The first group consisted of 16 people. Many did not believe it would be good for them to go, and several people withdrew right before departure. But those who went to Norway started to call home saying that things are good, and people began to ask to be allowed to go.

All the interviewees said that before migration they were sad to separate from their families and felt guilty leaving their children. Young mothers were scared to abandon small children, as is the case in female migration elsewhere (Hochschild 1979). Older mothers asked for their children to be included in the migration, crying and begging if refused. The main and pressing factor behind the migration decisions was to improve personal standards of living, the most common motivation for migration (Castles, de Haas, and Miller 2014). Natalia, aged 23, a woman recently married at the time of migration, said:

It was the only chance to get money. My relatives promised to help with the child. Most women who went to Norway had grandmothers to take care of the kids. My husband and I thought I would make 300 USD per month, but it was more - about 1,100 USD!

The hope to earn seven to eight times more than the average local salaries in a time when most people at home were almost starving mitigated other problems. Natalia continued: 'My husband did not like me leaving him. We quarrelled, but finally he let me go. He was satisfied with the prospect of the wages and the possibility to make savings.'

Most people in Teriberka stressed that the migration was motivated by poverty; however, some were adventurous, which aligns with Favell's (2008) argument about mixed motives for migration adding to simple cost-benefit calculations. Valeria, higher educated and in her mid-40s, was from the 'pioneer' group and stayed for three years. As she explained while living in Båtsfjord:

It was so exciting. I was curious and wanted to stay in a foreign country. The kids had grown up, and their father could care for them. I really liked to go and felt almost forced to use the opportunity.

Some migrants also highlighted that they felt good about the personal advancement. Nadia, aged 40, also interviewed while working in Båtsfjord, expressed the following: 'Before coming here, I could not talk to people as 
freely as I do now. I thought I was too old to go to Norway. [In Norway] I became brave.'

Besides satisfaction with the Norwegian salary, life in Båtsfjord was mostly rewarding. The early period of migration was dominated by euphoria. Natalia recalled her arrival:

It was 'wow' and 'oh.' All the lights at night, Båtsfjord looked like a diamond! Civilization... Everything was sterile at the factory. In the kolkhoz [in Teriberka], everything smells fishy. The streets [in Båtsfjord] were clean. Nice houses, beauty everywhere. Work was much easier than in the kolkhoz.

After a while, loneliness, disillusionment, and homesickness added to the positive emotions. These feelings related to limited contact with non-Russian people and the perception of sometimes being treated badly. Elena, aged 35, a trained engineer doing unskilled work in Båtsfjord, was not allowed to use her education and skills. She wanted a transfer to a skilled job, but the supervisor refused and told us what he also told Elena: 'Of course, she could not do those tasks. The equipment is expensive, and it requires experienced and skilled workers.' In addition to the migration regulation that permitted only unskilled work, in his view she did not possess the required skills and qualities, mostly held by men. Elena felt that 'Russians are the bottom of the pile. I, as a Russian, am not allowed this [opportunity].' Elena was frustrated by her subordination due to gender and nationality in Båtsfjord (Aure 2011), as well as homesickness and longing for her child left in Teriberka. As a single mother, she desperately needed money while also trying to prepare herself for a brighter future in the planned factory in Teriberka.

Norway became, for migrants and Russian organisers, a positive point of reference: everything was compared with how it was arranged in Norway, and, mostly, the Norwegian way was considered best - roads, houses, enterprises, salaries, people. One woman expressed the view of many while living in Båtsfjord:

It is clean here, nice, quiet, and there is a possibility to make big money. I like people - they are polite. In Russia, not all people are like that. Enterprises [in Norway] are better. It is like 'sky and earth' compared to Russia. Nothing is bad here.

Despite disillusionment, the positive emotions caused by migration experiences prevailed and the (positive) emotional capital among the group grew in terms of increased knowledge, experience, self-development, and selfawareness, along with the feeling that the migration verified their expectations and choices and improved their lives. 


\section{Dreams about the future back home}

Although there may be no direct links between the intentions, plans, and expectations of migration and the results after return (King 1986), migration phases, intentions, expectations, and outcomes are connected (see O'Reilly and Rye, Chapter 14). The Russian-Norwegian development plan for Teriberka included an export-oriented joint fish-processing plant, a water pipeline, maintenance, and improved electricity supply. The Norwegian partners claimed that they saw Teriberka as a model for building a fishing community in Russia while providing the Norwegian plant access to the scarce raw material (fish) and trained labour force. The Russian partners wanted to revive fisheries and make Teriberka a decent place to live and saw labour migration as a route to poverty reduction. They believed that the military control in Teriberka would be lifted, and it would become a zone of international economic development. Most migrants were 'home-oriented' and expected development in their village, based on the recovery of fisheries, internationalisation, and the development of new knowledge.

Valeria, 'home-oriented' with an education degree, highlighted the value of visits abroad, specifically learning new languages, working methods, and work organisation. She expected her new skills to benefit her and the planned plant, and thereby Teriberka's economic situation, leading to employment in a management position. She expected a new future for Teriberka, with international industries and modernisation of the Russian top-down management style. As another Russian woman explained: 'In Russia, the boss is The Boss. Most of our bosses are very... [bossy]; bosses and staff are not mixed. In Norway, after work, we can be equal.' Norway hence became a point of reference for the wished-for future in Teriberka. A manager in Teriberka said: 'If there could be any good investment programmes, we would imagine [Teriberka] as a village of the Norwegian type.' Another manager laughed at what he considered a collective naïve imaginary: 'We have a dream - to move with the entire village to Norway!' However, some migrants and villagers anticipated that nothing would change: the international project was established to 'earn on the Russian skin,' as Yuri, a migrant, put it:

Tales... The Teriberka project was established for other purposes. It is good to build a factory in Teriberka - cheap labour force, cheap energy - and have people with this certificate [from the Norwegian industry].

Nevertheless, we found, that despite doubts, there was a shared dream among migrants, businessmen, and people in Teriberka - a dream of Teriberka as a comfortable, joyful, Norwegian-type fishing village with an unbiased community life and vivid economic development. As an image, this 'new Teriberka' was often on people's minds. We suggest that this collective dream, produced by the experiences of labour migration in Norway, shaped aspirations, or 
imaginaries, for some before migration even started but also increasingly during the migration (Benson and Osbaldiston 2014). This dream, including its hopes, became part of the positive community-level emotional capital in Teriberka.

\section{Post-return: emotional capital devastation}

In three years, the labour migration ceased and the plans for an exportoriented plant in Teriberka collapsed due to Teriberka's status as a 'closed' border-zone settlement and lack of investment. Most migrants returned to Teriberka. Return migration has many causes: home orientation and planned return, plans for innovation in the home country, retirement, and some sort of failure (Cerase 1974). In this case the migration was temporary, and most migrants planned to go back and continue their life in Teriberka, feeling that they belonged there. Others lacked the opportunity, money, or work to move away and hence stayed.

While this migration was triggered by the harsh socio-economic situation and channelled by the migration organisation, it ceased due to the Norwegian migration regime. Specific migration policies thus impact return migration and its outcomes. In this case, the policies on temporary migration made it resemble long-term commuting. This demonstrates the blurriness of migration types and processes. Both business partners and migrants regarded the return as too early and felt unprepared, which is an important factor for the developmental outcome of migrants' return (Cassarino 2004). Frustration of the abrupt return became an emotional impact of the migration.

In the return phase, in the early 2000s, the situation in Teriberka was typical for most rural Russian settlements. Russian pro-market policies, which neglected the human dimension, were coupled with an absent state in rural areas, making the effects of reforms especially destructive for small rural places (Kalugina 2000). According to Wegren (2016, 7): 'The main story in rural Russia during the 1990s was a struggle for survival amidst economic collapse.' The number of villages in Russia decreased from 142,200 in 1989 to 132,200 in 2002 (Wegren 2016). Teriberka survived but most people endured poor quality of life due to high unemployment, alcohol problems, lack of maintenance, and declining municipal budgets. Young people lacked money to leave for work or education. The unemployment grant was 120 roubles per month, less than five USD (a decent wage would be 10 times more). Some people lived on their 'mama's neck' until they were 30, as one woman told us.

In the following years, many former migrants used the money earned in Båtsfjord for everyday expenses and savings, or they bought cars. Some bought flats in Murmansk for their children to use while studying. Most stayed in Teriberka and used their new skills at the kolkhoz's fish factory. The main visible results from migration were, however, that former migrants paid more attention to home decoration. The women who had returned tried to make 
their homes look nice, putting effort into buying furniture in Murmansk and bringing it to Teriberka, traversing the $200 \mathrm{~km}$ in hired cars on unpaved roads. This was not just an issue of decorating - this was making their everyday lives better, making themselves feel better. During our visit, they proudly showed us their efforts to make the best of their homes in a dilapidated environment. People with whom they shared the migration experience recognised and reinforced their efforts by supporting each other at an identity level. Appleyard (1989) describes this as 'conspicuous consumption' applying the expression in the migration context. This fails to acknowledge the importance of dignity in a situation of economic insecurity and depression.

Returning to life in Teriberka evoked pain and despair even worse than that before migration. The emotional experiences from Norway influenced migrants' views on Teriberka: 'Before, I did not notice that I live in ruins. When I came back home, it was like I saw my village for the first time: it looked like after the war' (Nadia). The experiences from the migration turned to shame and painful resignation, made the re-integration difficult, and triggered a downward spiral of positive emotional capital devastation. In a self-escalating cycle, negative emotions may escalate into negative externalities (Turner 1999) and produce a sense of paralysis (Gray 2008). In Teriberka people experienced sorrow: the place that former migrants called their own was now unable to provide them with the life they wanted. A villager said: 'How can people live in Teriberka after they lived in Norway? This is a big question...'

The previous glory of Teriberka, its continuous decline, and the emotions related to migration became unbearable. We saw the tears and despair of former migrants, and people talked about some villagers wanting to hurt themselves - those who could not bear the pain of the destruction of their home community. Households longed to move, and internal remigration occurred, which is common after return migration (Cassarino 2004) and emphasises the emotional strain and stress in return migration (Kunuroglu et al. 2016, Christou 2006). Both the self-confidence and money from migration contributed to such movements, while the Norwegian work experience also helped some people to obtain new jobs outside Teriberka. We found that, rather than inspiring positive development through the experience and emotional capital gained, return migration and the lack of state support for the exhausted village, produced negative feelings and increased negative emotional capital at the individual, group, and community levels, as Turner (1999) discusses. This produced a dichotomy between people who migrated and those who stayed in Teriberka. One of the kolkhoz leaders said: 'People went to Norway, earned easy money, and came back to poverty. We wanted to improve [the] situation here, at home.'

Studies on entrepreneurship in post-Soviet Russia reveal a legacy of the Soviet state in the form of people's negative attitudes to individual entrepreneurial activity (Petrovskaya, Zaverskiy, and Kiseleva 2017). In Teriberka, 
this legacy contributed to the failed effects of positive migration experiences. We saw almost no new private economic initiatives or investments of migration money into local businesses. An exception was the family of a woman who worked in Båtsfjord buying a boat and organising fishing tours, partly using migration money. We found no social initiatives from former migrants, though they met individually and celebrated holidays together. We explain this by the disillusionment following the migration and the deep depression in Teriberka. 'It looked like a village forgotten by the state, by businessmen, by everybody,' one of the migrants said. This made people indifferent, apathetic, and passive. People longed for the Soviet past when the state was responsible for many aspects of people's lives. A Russian businessman said: 'The problem is that depression in Teriberka influenced people in a negative way - they are not committed.' Apathy, as a state of indifference and the suppression or even absence of emotions (Marshall 2012), is destructive to people's minds. At the community level, apathy leads to the nullification of emotional capital. The absence of emotions such as concern, motivation, or passion, hinders positive activity and development; this characterised Teriberka after migration.

\section{Twenty years later}

After two decades, the experience of labour migration is still remembered in the continuously declining Teriberka. When interviewing Irina and Anna in 2015, we found that positive emotions still dominated their memories of Båtsfjord. Both women, now in their late 40s, smiled warmly when recalling migration. They were happy to host the Norwegian researcher and wished to return and work in fish processing. Irina dreamily said: 'I would love to go to Norway again.' Obviously, this wish was not only related to economic considerations; they were longing for their positive experiences and emotions during migration.

Sitting in Irina's flat, we saw the elegant furniture that greatly contrasted with the view from the window of the ruined buildings that are everywhere in contemporary Teriberka. Paintings of fishing boats on the wall and old souvenirs from Norway were visible. The women told us how groups of former migrants continue to meet as they did for years after returning, but lately more families are moving away and only a few of their fellow migrants still live in Teriberka. These two women gained skills in Båtsfjord that were useful at the factory in Teriberka, but the factory later closed and their skills lost value.

The movie Leviathan, a Golden Globe winner of 2015 and filmed in Teriberka, introduced a new era. Tourism is growing while the fisheries continue to decline. Large numbers of visitors arrive to see the coast and northern lights, but the consequent developments are not influencing the lives of former migrants or most local inhabitants. Some women said in the interviews that to start even a small business to provide food for tourists would be impossible 
for them: they did not believe that they would be able to sell their product, and they were afraid to run into problems regarding taxation or competition. They did not see themselves as entrepreneurs and the idea of undertaking any new activity seemed unrealistic and even exotic to them. Human capital increased during migration, but emotional capital did not appear to be a stable stock of resources to be drawn on - being relational, dynamic, and contextual.

However, the 'dream' of Teriberka as a Norwegian-type village is still alive and continues to circulate among people and in local and regional political debates. During our last talk with Irina and Anna, it became clear that the biggest chance to use the positive emotional capital gained by the migrants, at the community level, was immediately after their return. But this chance (and resource) was lost by not being addressed properly and in a timely manner; it might not even have been noticed at the community level.

\section{Emotions in migration and post-return community development}

The migration from Teriberka for work in the fish-processing industry in Båtsfjord involved emotions ranging from the deepest despair to the highest excitement for migrants, their families, and other people in the Russian community. While rational economic concerns are usually considered core motivations for labour migration, we have found that emotions strongly direct how migrants even recognise opportunities and formulate migration considerations. The focus on emotions revealed how difficult the insecurity and separation from children were. It highlighted how the desperate situation in Teriberka combined with the prospects of making 'big' money and dreams for positive outcomes of migration allowed migrants to negotiate the pain, guilt, and fear of separating from their children, families, and community. The joy of new experiences could grow, despite migrants' loneliness and disillusionment.

The focus on emotions helped us understand how the expectations and considerations before and during migration were mixed and yet important in forming migration experiences. The emotional aspects, including increasing knowledge, gaining experience, self-development, and the feeling that the migration eventually verified migrants' choices and improved their lives, are important factors in understanding migrants' increased human capital.

This chapter shows how migrants, after the return, used their experiences from abroad in individual everyday strategies but to a much lesser degree at the community level. It shows how new skills, self-awareness, and money made some migrants relocate in Russia after the migration ended, while others managed to secure their children's future. At the individual level, some migrants grew stronger and kept their pride and dignity in post-migration times by providing a more pleasant home environment for themselves and 
their families in the midst of the dilapidated ruin in which they live. We argue that the so-called 'conspicuous consumption' signals the strong emotions involved, such as shame, as well as self-esteem, and respect for human life, in a situation where these are threatened.

The migration experiences also caused collective frustration, by making the depressing situation in Teriberka more visible to migrants who returned, and fuelled a downward spiral of passivity and apathy. The positive emotional capital accumulated during migration was depleted by negative emotions in the post-return period. This capital was not used in a timely manner at the community level after migrants' return, and it did not catalyse development in the home village. It eventually vanished. The depletion of the community's positive emotional capital undermined motivation for actions that could produce development in the village. The lack of both local and state rural development policies, the Soviet state's legacy of scepticism of individual entrepreneurial activity, the vanished emotional capital, and apathy all worked in concert to hinder post-migration community development. Today, the remaining positive emotional experiences from migration exist mainly at the individual level. However, these memories and the dream of a Norwegian-type Teriberka actually became a part of the community's cognitive map, referred to and talked about 20 years later. This makes many people long for the former Soviet state.

Our study shows that emotions are highly important in migratory decisions, during migration, for the processes after return, and the outcomes of migration for the community of return. Focusing on emotions provides a new insight into post-migration community development and aids the understanding of how emotions are inherent in other structures and that lack of development after return migration relates to the depletion of the positive emotional capital gained during the migration. Emotional capital, which constitutes an important resource for positive action, may vanish through negative post-return emotions, strengthened by downward development of the home community in the absence of proper state rural public policies. Paradoxically, the focus on emotions highlights the importance of economy and politics but also reveals the significance of emotional aspects of these 'rational' structures. The chapter thus adds to the understanding of the ambiguity of international mobility in rural places, the role of emotions in migration, and the role of emotions in origin-community development after the migrants' return.

\section{Acknowledgement}

Riabova's work on the chapter was supported by the Ministry of Education and Science of the Russian Federation (project AAAA-A18-118051590115). The publication charges for this article have been funded by a grant from the publication fund of UiT The Arctic University of Norway. The authors wish to thank the external reviewers for their comments to the manuscript. 


\section{References}

Ahmed, S. 2004. The Cultural Politics of Emotion. Edinburgh: Edinburgh University Press.

Appleyard, R.T. 1989. 'Migration and Development: Myths and Reality.' International Migration Review 23(3): 486-499. DOI:10.1177/019791838902300305.

Aure, M. 2008. 'Arbeidsmigrasjon fra Teriberka til Båtsfjord 1999-2002 [Labour Migration from Teriberka to Båtsfjord 1999-2002].' Ph.D. diss., University of Tromsø.

Aure, M. 2011. 'Borders of Understanding: Re-Making Frontiers in the RussianNorwegian Contact Zone.' Ethnopolitics 10(2): 171-185. DOI:10.1080/17449057. 2011.570981.

Aure, M. 2013. 'The Emotional Costs of Employment-Related Mobility.' Norsk Geografisk Tidsskrift 67(5): 284-294. DOI:10.1080/00291951.2013.847855.

Aure, M., A. Førde and T. Magnussen. 2018. 'Will Migrant Workers Rescue Rural Regions? Challenges of Creating Stability through Mobility.' Journal of Rural Studies 60: 52-59. DOI:10.1016/j.jrurstud.2018.03.005.

Benson, M. and N. Osbaldiston, 2014. Understanding Lifestyle Migration. London: Palgrave Macmillan.

Burkitt, I. 1997. 'Social Relationships and Emotions.' Sociology 31(1): 37-55. DOI:10.1177/0038038597031001004.

Carling, J. and F. Collins. 2018. 'Aspiration, Desire and Drivers of Migration.' Journal of Ethnic and Migration Studies 44(6): 909-926. DOI:10.1080/1369183X.2017.1384134.

Cassarino, J-P. 2004. 'Theorising Return Migration: The Conceptual Approach to Return Migrants Revisited.' International Journal on Multicultural Societies 6(2): 253-279.

Castles, S., H. de Haas and M.J. Miller. 2014. The Age of Migration: International Population Movements in the Modern World. New York: The Guildford Press.

Cerase, F.P. 1974. 'Expectations and Reality: A Case Study of Return Migration from the United States to Southern Italy.' The International Migration Review 8(2): 245-262.

Christou, A. 2006. Narratives of Place, Culture and Identity: Second-Generation GreekAmericans Return 'Home.' Amsterdam: Amsterdam University Press.

Favell, A. 2008. Eurostars and Eurocities: Free Movement and Mobility in an Integrating Europe. Oxford: Blackwell.

Gendron, B. 2017. 'Emotional Capital: The Set of Emotional Competencies as Professional and Vocational Skills in Emotional Works and Jobs.' Revista espanola de educacion comparada 29: 44-61. DOI:10.5944/reec.29.2017.17433.

Gray, B. 2008. 'Putting Emotion and Reflexivity to Work in Researching Migration.' Sociology 42(5): 935-952. DOI:10.1177/0038038508094571.

Halfacree, K. 2004. 'A Utopian Imagination in Migration's Terra Incognita? Acknowledging the Non-Economic Worlds of Migration Decision-Making.' Population, Space and Place 10(3): 239-253. DOI:10.1002/psp.326.

Heady, P. and L.L. Gambold Miller. 2006. 'Nostalgia and the Emotional Economy: A Comparative Look at Rural Russia.' In Postsocialism: Politics and Emotions in Central and Eastern Europe, edited by M. Svašek, 34-52. New York: Berghahn Books. 
Hochschild, A.R. 1979. 'Emotion Work, Feeling Rules, and Social Structure.' American Journal of Sociology 85: 551-575. DOI:10.1086/227049.

Kalugina, Z.I. 2000. 'Survival Strategies of Enterprises and Families in the Contemporary Russian Countryside.' In Russian Views of the Transition in the Rural Sector: Structure, Policy Outcomes, and Adaptive Responses, edited by L.A. Norsworthy, 118-131. Washington, D.C.: The World Bank.

King, R. 1986. 'Return Migration and Regional Economic Development: An Overview.' In Return Migration and Regional Economic Problems, edited by R. King, 1-37. London: Routledge.

Kunuroglu, F., F. van de Vijver and K. Yagmur. 2016. 'Return Migration.' Online Readings in Psychology and Culture 8(2): 1-28. DOI:10.9707/2307-0919.1143.

Markussen, T. 2006. 'Moving Worlds. The Performativity of Affective Engagement.' Feminist Theory 7(3): 291-308. DOI:10.1177/1464700106069038.

Marshall, J.C. 2012. 'Apathy in Learning.' In Encyclopedia of the Sciences of Learning, edited by N.M. Seel, 275-276. Boston, MA: Springer US. DOI:10.1007/978-1-44191428-6_997.

Nowotny, H. 1981. 'Women in Public Life in Austria.' In Access to Power: CrossNational Studies of Women and Elites, edited by C.F. Epstein and R.L. Coser, 147156. London: George Allen and Unwin.

O'Reilly, K. 2014. 'The Role of the Social Imaginary in Lifestyle Migration: Employing the Ontology of Practice Theory.' In Understanding Lifestyle Migration, edited by M. Benson and N. Osbaldiston, 211-234. London: Palgrave Macmillan.

Petrovskaya, I.A., S.M. Zaverskiy and E.S. Kiseleva. 2017. 'Attitude to Entrepreneurship in Russia: Three-Dimensional Institutional Approach.' Advances in Systems Science and Applications 2(17): 29-43. DOI:10.25728/assa.2017.17.2.483.

Reay, D. 2000. 'A Useful Extension of Bourdieu's Conceptual Framework? Emotional Capital as a Way of Understanding Mothers' Involvement in Their Children's Education?' Sociological Review 48(4): 568-585. DOI:10.1111/1467-954X.00233.

Riabova, L. 2001. 'Coping with Extinction: The Last Fishing Village on the Murman Coast.' In The Reflexive North, edited by N. Aarsæther and J.O. Bærenholdt, 115138. Copenhagen: MOST and Nordic Council of Ministers.

Riabova, L. and L. Ivanova. 2009. 'Fishery Governance in Northwest Russia.' In The Changing Governance of Renewable Natural Resources in Northwest Russia, edited by S. Nysten-Haarala, 77-103. Farnham: Ashgate Publishing Limited.

Svašek, M. 2008. 'Who Cares? Families and Feelings in Movement.' Journal of Intercultural Studies 29(3): 213-230. DOI:10.1080/07256860802169170.

Svašek, M. 2010. 'On the Move: Emotions and Human Mobility.' Journal of Ethnic and Migration Studies 36(6): 865-880. DOI:10.1080/13691831003643322.

Tanner, K.J. 2005. 'Emotion, Gender and the Sustainability of Communities.' The Journal of Community Informatics 1(2): 121-139.

Turner, J.H. 1999. 'The Formation of Social Capital.' In Social Capital: A Multifaceted Perspective, edited by P. Dasgupta and I. Serageldin, 94-146. Washington, D.C.: World Bank.

Vathi, Z. and V. Duci. 2015. 'Making Other Dreams: The Impact of Migration on the Psychosocial Wellbeing of Albanian-origin Children and Young People upon Their Families' Return to Albania.' Childhood, 23(1): 53-68. DOI:10.1177/ 0907568214566078. 
Voronov, M. 2013. 'Emotional Capital and Institutional Reproduction.' Academy of Management Proceedings 2013(1): 11152-11152. DOI:10.5465/ambpp. 2013.11152abstract.

Wegren, S.K. 2016. 'The Quest for Rural Sustainability in Russia.' Sustainability 8(7). DOI:10.3390/su8070602. 